\title{
Lissencephaly-pachygyria and cerebellar hypoplasia in a calf
}

\author{
Lisencefalia-paquigiria e hipoplasia cerebelar em um bovino
}

\author{
Bianca Lemos dos Santos ${ }^{I}$ Maria Cecília Florisbal DaméII Ana Carolina Barreto Coelho \\ Plínio Aguiar Oliveira ${ }^{\mathrm{I}}$ Clairton Marcolongo-Pereira ${ }^{\mathrm{III}}$ Ana Lucia Schild ${ }^{\mathrm{IV}}$
}

\section{ABSTRACT}

A case of lissencephaly-pachygyria and cerebellar hypoplasia diagnosed in a Charolais $x$ Tabapuã calf is described. The calf presented since birth, clinical signs characterized by apathy, prolonged recumbency, tremors of the head and neck, ataxia, hypermetria, difficulty walking, blindness and swelling of the joints of the four limbs. Due to the unfavorable prognosis, the animal was euthanized and necropsied at 34 days of age. At necropsy, a rudimentary development of the brain folds (gyri) and grooves (sulci) was observed, and the cerebellum was hypoplastic. The cut surface of the brain exhibited thickening of the gray matter (pachygyria) in the frontal, parietal, temporal and occipital cortices and narrowing of the white matter. In the organs of the thoracic and abdominal cavities, no significant lesions were observed. Histologically, cerebral cortex was thick and exhibited neuronal disorganization of the gray matter. The cerebellum had a thin molecular layer, and neuronal disorganization with ectopia of the Purkinje neurons in the region of the granular and molecular layers. There were no bacterial growths in cultures of joint swabs. This was the only case on the property, which suggests that this malformation, which has not previously been described in cattle, was a sporadic case, and it was not possible to determine its cause. Neurological lesions and clinical sings presented here should be considered in the differential diagnosis of congenital diseases of the central nervous systems of cattle.

Key words: lissencephaly, pachygyria, cerebellar hypoplasia, congenital malformation, cattle.

\section{RESUMO}

Descreve-se um caso de lisencefalia-paquigiria e hipoplasia cerebelar diagnosticado em um bovino, macho, cruza Charolês x Tabapuã que apresentava, desde o nascimento, sinais clínicos caracterizados por apatia, decúbito prolongado, tremores da cabeça e do pescoço, ataxia, hipermetria, dificuldade na marcha, cegueira e aumento de volume nas articulações dos quatro membros. Devido ao prognóstico desfavorável, o bovino foi eutanasiado e necropsiado aos 34 dias de idade. Na abertura da caixa craniana, observou-se formação rudimentar dos giros do telencéfalo e cerebelo hipoplásico. Ao corte o encéfalo, apresentava espessamento da substância cinzenta (paquigiria) do córtex frontal, parietal, temporal e occipital e estreitamento da substância branca. Nos órgãos das cavidades torácica e abdominal, não foram observadas lesões significativas. Histologicamente, no córtex cerebral havia desorganização neuronal da substância cinzenta que estava espessa. No cerebelo, havia diminuição da camada molecular e desorganização neuronal com ectopia dos neurônios de Purkinje na região das camadas granular e molecular. Não houve crescimento bacteriano das culturas de suabes das articulações. O fato de ser o único caso na propriedade sugere que a malformação, sem descrição anterior em bovinos, trata-se de caso esporádico, não sendo determinada sua causa. As alterações neurológicas aqui observadas devem ser levadas em consideração no diagnóstico diferencial de enfermidades congênitas do sistema nervoso central de bovinos.

Palavra-chave: lisencefalia, paquigiria, hipoplasia cerebelar, malformação congênita, bovinos.

\section{INTRODUCTION}

Lissencephaly is a malformation of the telencephalon that occurs due to neuronal migration disorder and leads to the failure of the formation of the cerebral convolutions, which results in a smooth

\footnotetext{
IPrograma de Pós-graduação em Medicina Veterinária, Faculdade de Veterinária (FV), Universidade Federal de Pelotas (UFPel), Pelotas, RS, Brasil.

IEMBRAPA Clima Temperado, Capão do Leão, RS, Brasil.

IIIFaculdade de Veterinária, UniRitter, Porto Alegre, RS, Brasil.

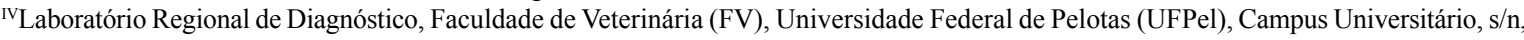
96010-900, Pelotas, RS, Brasil. E-mail: alschil@terra.com.br. Corresponding author.
} 
appearance of brain surface. Lissencephaly may involve the complete absence of gyri (agyria) or a reduction in the number of gyri. In this condition, abnormal thickening of the cortical mantle (pachygyria) occurs, and there is a loss of the cortical laminar pattern involving the presence of four layers rather than six (DE LAHUNTA \& GLASS 2009; MACKILLOP, 2011). The malformation may present different degrees of severity that range from one to six with one being the most severe degree (DOBYNS \& TRUWIT 1995). Neuronal migration disorders are a heterogeneous group of congenital defects that occur due to disorders involving the migration of immature neurons from their origins in the ventricular and subventricular zones toward their target locations in the cerebral cortex during embryonic development (HERRMANN et al., 2011). These disorders occur due to the post-mitotic neurons' inability to reach their final destinations and correctly populate the cortical plate of the cerebral cortex, which leads to abnormal cortical thickness and reduced or absent gyri and sulci on the cortical surface (WYNSHAW-BORIS et al., 2010).

In addition to humans, lissencephaly has been reported in dogs including Lhasa Apsos (LEE et al., 2011), wire fox terriers, Irish setters, samoyeds, in undefined breeds, a Korat cat (DE LAHUNTA \& GLASS 2009), goats (SANTOS et al., 2013) and sheep (PÉREZ et al., 2013). In most cases, lissencephaly occurs with other brain malformations, such as microcephaly, cerebellar hypoplasia and hypoplasia of the corpus callosum. Etiologies in animals remain uncertain. However, it is believed that lissencephaly is more closely associated with genetic inheritance than teratogenic agents. Clinical signs in animals consist of seizures, visual deficits or blindness, abnormalities in behavior and limited mobility (LEE et al., 2011). In humans, lissencephaly has been described as type I (classical) and type II (cobblestone) and is associated with congenital muscular dystrophy and ocular abnormalities (GOLDEN, 2001; PILZ et al., 2002). These diseases are believed to have a genetic basis and have been linked to mutations and/or deletions in the double cortin (DCX), filamin-1, LIS1, reelin (RENL), tubulin (TUBA1A), and aristaless-related homeobox (ARX) genes, (DOBYNS et al., 1993; HONG et al. 2000; AYALA et al., 2007; HERRMANN et al., 2011). In sheep with lissencephaly and cerebellar hypoplasia, a deletion of 31 base pairs in the RENL gene has been identified (SUÁREZ-VEGA et al., 2013).

The objectives of this study were to describe the clinical-pathological findings related to lissencephaly-pachygyria and cerebellar hypoplasia observed in a single calf to establish the differential diagnosis with other diseases of the central nervous systems of young cattle.

\section{MATERIALS AND METHODS}

A 34-day-old calf with neurological disorders since birth was referred to the Laboratório Regional de Diagnóstico (LRD) of Faculdade de Veterinária da Universidade Federal de Pelotas (UFPel). Due to the poor prognosis, the calf was euthanized and necropsied. Fragments of the organs of the thoracic and abdominal cavities and the central nervous system were collected and fixed in $10 \%$ buffered formalin. The materials were routinely processed for histological analyses and stained with hematoxylin-eosin (HE). To rule out infection with bovine viral diarrhea virus (BVDV), 3-mm thick paraffin blocks of fragments of the skin, lymph nodes and cerebral cortex were cut and submitted to immunohistochemistry according to the technique described by SANTOS et al. (2011) using a commercial monoclonal primary antibody anti-BVDV 15C5 (Syracuse Bioanalytical, Ithaca, NY, United States) at a dilution of 1:500. Slides of the cerebral cortex of a positive case were used as positive control, and the primary antibody was replaced with PBS for negative control.

\section{RESULTS}

A 34-day-old male Charolais x Tabapuã calf from the municipality of Encruzilhada do Sul, Rio Grande do Sul was referred to the LRD/ UFPel. This calf was part of a herd of 80 calves. The animals were raised on a natural pasture. The neurological signs were characterized by apathy, prolonged recumbency, tremors of the head and neck, hypermetria, ataxia, difficulty walking, and blindness; the latter was evidenced by the calf's aimless walking and striking against fences and objects. Increases in the volumes of the tibias relative to the metatarsal joints and the radioulnar joints of the four limbs were also observed (Figure 1). Necropsy revealed pus in the umbilicus and in one of the four joints. Upon the opening of the skull, a brain with rudimentary development of the anatomical gyri and sulci that resulted in a smooth brain surface was observed (Figure 2A). The cerebellum was hypoplastic with marked decreases in the sizes of the cerebellar sheets in both hemispheres and the vermis compared with the cerebellum of a control bovine of the same age (Figure 2B). No significant changes were noted in the other organs. 


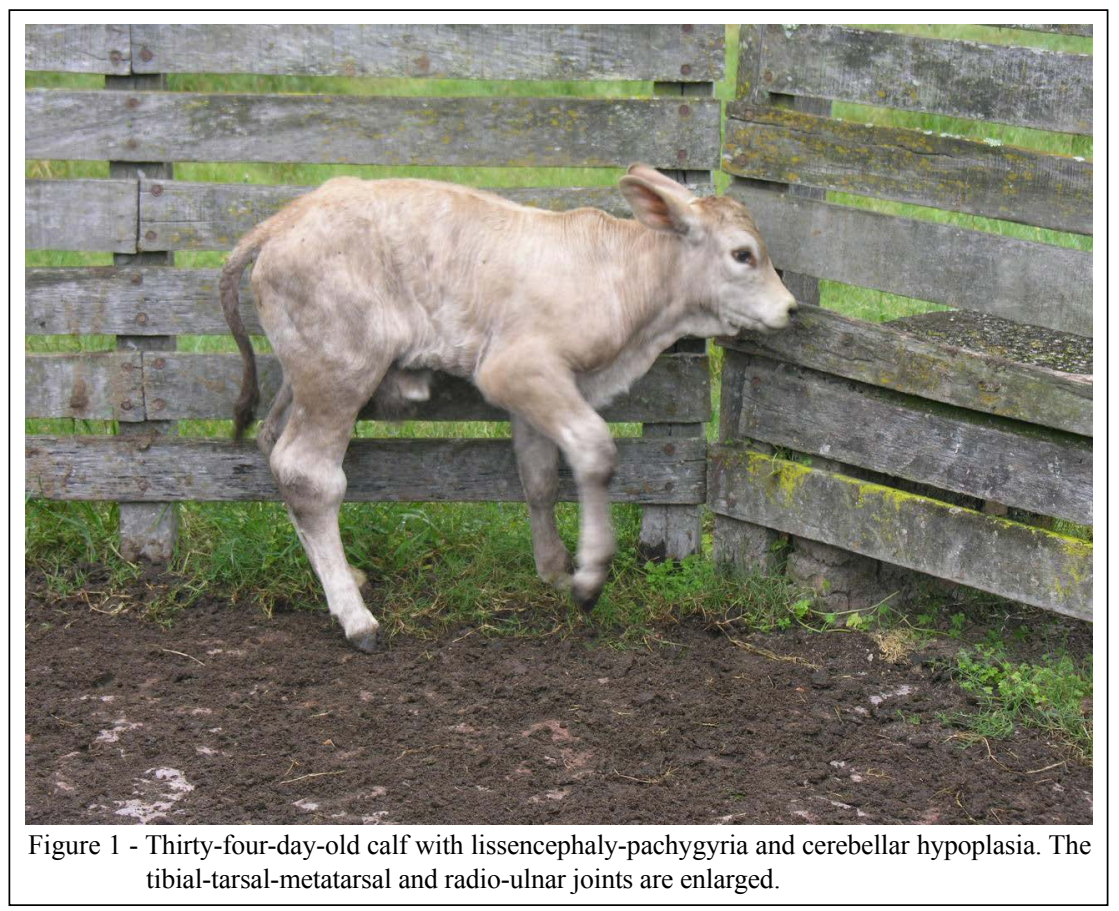

Cross-sections of the brain revealed agyria and thickening of the gray matter (pachygyria) in the frontal, parietal, temporal and occipital cortices and narrowing of the white matter of the cortex (Figure 3A) compared with the same parts of a control calf brain (Figure 3B). The remaining gyri were wide, the sulci were shallow, and there were rare interdigitations between the gray and white matters (Figure 3A). The caudate nucleus, thalamus, the corpus callosum, hippocampus and brain stem were normally developed.
Histologic examination of the brain revealed neuronal disorganization in the cerebral cortex and thick gray matter with no normal laminar flow. The cerebellum exhibited a decreased molecular layer and neuronal disorganization with ectopia of the Purkinje neurons in the region of granular and molecular layers (Figure 4). No bacterial growths were observed in cultures of the pus from the umbilicus and joint. No positive staining was observed following immunohistochemistry for BVDV antigens.
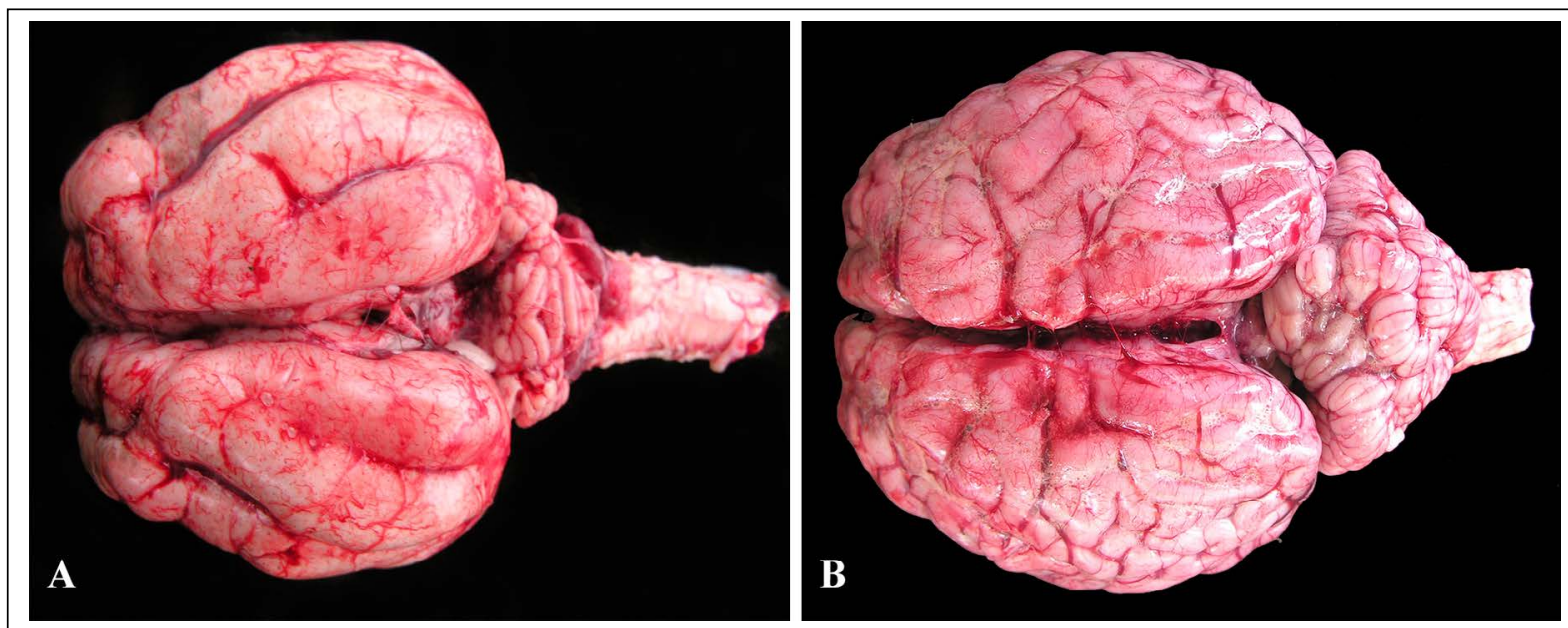

Figure 2 - The brain of the calf with lissencephaly-pachygyria and cerebellar hypoplasia. A. The cerebral hemispheres exhibit few and poorly developed sulci. The cerebellum appears hypoplastic. B. Brain of a control calf of the same age. 


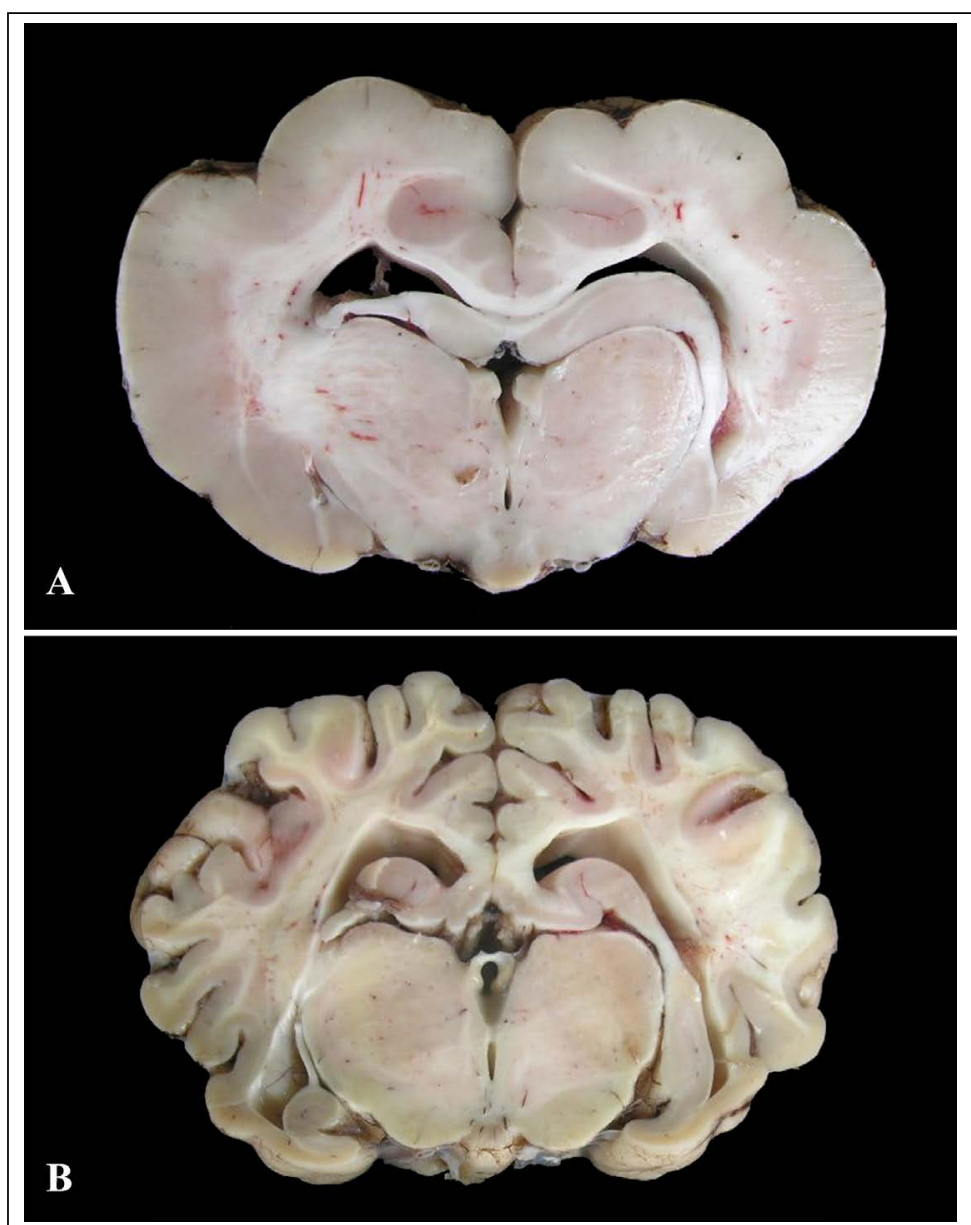

Figure 3 - A. Transverse section of the brain of the calf with lissencephaly-pachygyria and cerebellar hypoplasia. A marked increase in the thickness of the cerebral cortex of the affected calf is shown. The white matter is thin. B. Transverse section of the control calf brain.

\section{DISCUSSION}

The diagnosis of lissencephaly-pachygyria andcerebellarhypoplasiawasbased on themacroscopic changes and histopathological examinations of the affected bovine brain. Lissencephaly-pachygyria is a rare anomaly in domestic animals andwas not previously been described in bovines. The lesions are due to abnormalities in the migration of neurons during embryonic development that result in the malformation of the cerebral cortex (TIAN et al., 2008). Injuries observed in this case were classified as grade II in severity based on the classification of classical lissencephaly that has been described for humans. Grade II lissencephaly is characterized by diffuse agyria with few shallow sulci over the frontal, temporal or occipital lobes and diffuse pachygyria (DOBYNS \& TRUWIT, 1995). Cerebellar hypoplasia typically occurs concurrently with lissencephaly in the classic form of the disease (DOBYNS WB \& TRUWIT, 1995; GOLDEN, 2001). In the cases that have been described in cats (HERRMANN et al., 2011), lambs (PÉREZ et al., 2013), and a goat (SANTOS et al., 2013), the disease has assumed the classic form with cerebellar hypoplasia.

In the present case, the calf exhibited marked cerebellar signs, cortical blindness and depression, and it was euthanized at 34 days of life. Dogs and cats apparently exhibit better adaptations to the cortical and cerebellar alterations, and the clinical signs are often more discreet. These animals can survive for long periods of time but exhibit depression, aggression, and visual impairment (GREENE et al., 1976; HERRMANN et al., 2011; LEE et al., 2011). The animals' survival times can make diagnoses difficult in these cases. In the present case, the first suspected 


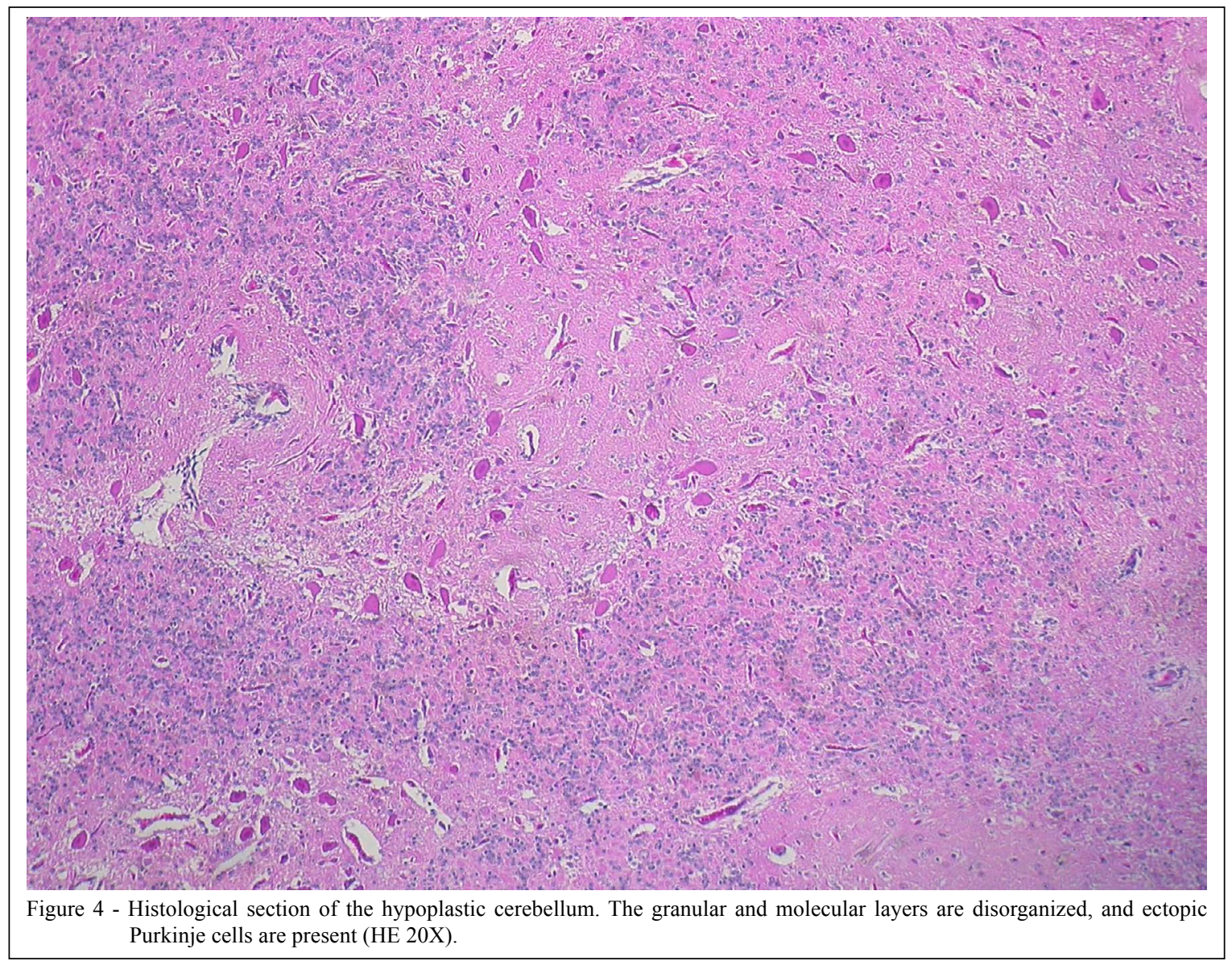

diagnosis was cerebellar hypoplasia; however, the calf presented with cortical signals and swelling of the joints, which indicated polyarthritis. The more prominent signs were motor incoordination and intention tremors of the head and neck, which are related to cerebellar hypoplasia because the cerebellum coordinates motor functions in mammals (KING, 1994). One description of the disease in a goat mentioned that the cerebellar signs were more intense, which suggests that a high degree of cerebellar cortical dysfunction may mask the signs (SANTOS et al., 2013).

Heterotopia of the Purkinje neurons in the granular layer of the cerebellum was a striking finding of the present case, and the hypermetria, ataxia and tremors of the head and neck observed here were likely associated with this change. These clinical signs were similar to those reported in cases of lissencephaly and cerebellar hypoplasia in dogs, cats (MACKILLOP, 2011), and humans (AYALA et al., 2007).

Among the entire herd, only this bovine was affected based on the information provided by the owner, and no inflammatory lesions were observed in the central nervous system (CNS) based on the negative immunohistochemistry results regarding the detection of BVDV antigens. Together, these findings suggest that the defect observed in this calf was not infectious in origin. Intrauterine lesions caused by toxic agents, hypoxia, and/or ischemia and trauma can cause cortical and cerebellar malformations due to the destruction of cells and immature neurons (MACKILLOP, 2011). However, in this case, there was no evidence that any of these factors could have caused the malformations. The parents of the affected cattle were eliminated from the reproduction system of the farm. The possibility of a hereditary origin of this disease is presumed to be remote because dominant gene transmission usually affects a greater number of animals within the herd. In this case, only one calf exhibited the defect. Nevertheless, recessive gene transmission requires inbred crossing, which did not occur in this case because the calf was the result of the crossing two different breeds.

The congenital malformation of the central nervous system described here demonstrates the 
importance of the differential diagnoses of diseases that cause neurological clinical manifestations in young cattle. Intrauterine BVDV infection should be considered in the differential diagnosis because the clinical signs of cerebellar dysfunction are similar and also manifest at birth. However, lissencephaly has not yet been described in cases of malformations due to BVDV infection. Bluetongue virus can also cause CNS malformations of bovine fetuses that are accompanied by non-suppurative meningitis, but this lesion was not observed in this case. It has been reported that severe infections of fetuses are rare, and cows infected with Bluetongue virus typically have healthy and uninfected calves (OBERST, 1993). Cattle are considered reservoirs of the virus and rarely have the disease (ANTONIASSI et al., 2010). Other viruses, such as Akabane virus, Rift Valley Fever virus, Cache Valley virus, Border disease virus, and Wesselsbron disease virus, are also associated with the occurrence of CNS malformations (OBERST, 1993), but these viruses have not yet been diagnosed in cattle in Brazil. The fetal injuries that result from infections with these viruses are most often described as hydranencephaly, porencephaly, cerebellar hypoplasia, retinal dysplasia, microcephaly and arthrogryposis of neurogenic nature, among others (OBERST, 1993). Brain abscesses due to umbilical infections can also be confused with this disease. However, in such cases, the clinical signs appear sometime after birth. We concluded that in this case, the disease appeared to be a sporadic occurrence, as has been described in other domestic species.

\section{ACKNOWLEDGEMENTS}

\author{
We thanks for Conselho Nacional de \\ Desenvolvimento Científico e Tecnológico (CNPq) and \\ Coordenação de Aperfeiçoamento de Pessoal de Nível Superior \\ (CAPES) for scholarship.
}

\section{REFERENCES}

ANTONIASSI, N.A.B. et al. Clinical and pathological changes in sheep naturally infected with blue tongue virus in Rio Grande do Sul, Brazil. Pesquisa Veterinária Brasileira, v.10, n.12, p.1010-1016, 1993. Available from: $<$ http://www.scielo.br/scielo. php?script $=$ scipdf\&pid $=$ S0100-736X2010001200002\&lng=em\&n $\mathrm{rm}=\mathrm{iso} \& \operatorname{tlng}=\mathrm{pt}>$. Accessed: Jan. 20, 2016. doi: 10.1590/S0100736X2010001200002.

AYALA, R. et al. Trekking across the brain: The journey of neuronal migration. Cell, v.128, n.12, p.29-44, 2007.Available from: <http://dx.doi.org/10.1016/j.cell.2006.12.021>. Accessed: Sept. 15, 2015. doi: 10.1016/j.cell.2006.12.021.
DE LAHUNTA, A.; GLASS, E. Development of nervous system: malformation. In: _. Veterinary neuroanatomy and clinical neurology. 3.ed. Saint Louis, Missouri: Saunders Elsevier, 2009. Cap.3, p.23-53.

DOBYNS, W.B. et al. A human brain malformation associated with deletion of the LIS1 gene located at chromosome $17 \mathrm{p} 13$. Journal American Medical Association, v.270, n.23, p.28382842, 1993. Available from: <http://jama.jamanetwork.com/ article.aspx? articleid $=409789>$. Accessed: Jan. 17, 2015. doi: 10.1001/jama.1993.03510230076039.

DOBYNS, W.B.; TRUWIT C.L. Lissencephaly and other malformations of cortical development: 1995 update. Neuropediatrics, v.26,n.3,p.132-147, 1995.Available from: <https:// www.thieme-connect.com/DOI/DOI?10.1055/s-2007-979744>. Accessed: Feb. 01, 2015. doi: 10.1055/s-2007-979744.

GOLDEN, J.A. Annotation cell migration and cerebral cortical development. Neuropathology and Applied Neurobiology, v.27, p.22-28, 2001. Available from: <http://onlinelibrary.wiley.com/ doi/10.1046/j.0305-1846.2001.00307.x/abstract?userIsAuthentica ted $=$ false $\&$ deniedAccessCustomisedMessage $=>$. Accessed: Mar. 10, 2015. doi: 10.1046/j.0305-1846.2001.00307.

GREENE, C.E. et al. Lissencephaly in two Lhasa Apso dogs. Journal of the American Veterinary Medicine Association, v.169, n.4, p.405-410, 1976. Available from: <http://europepmc. org/abstract/med/956022>. Accessed: Mar. 15, 2015.

HERRMANN, A. et al. Lissencephaly and microencephaly combined with hypoplasia of corpus callosum and cerebellum in a domestic cat. Tierarztlihe Praxis Kleintiere, v.2, p.116120, 2011. Available from: <http://www.tieraerztliche-praxis $>$. Accessed: Mar.15, 2015.

HONG, S.E. et al. Autosomal recessive lissencephaly with cerebellar hypoplasia is associated with human RELN mutations. Nature Genetics, v.26, p.93-96, 2000. Available from: <http:// www.nature.com/ng/journal/v26/n1/abs/ng0900_93.html>. Accessed: Feb. 05, 2015.doi: 10.1038/79246.

KING, A.S. Cerebellumn In: KING, A.S. Physiological and clinical anatomy of the domestic mammals. Oxford: Oxford Science Publication, 1994. V. 1. Cap.15, p.171-182.

LEE, K.I. et al. Clinical and MRI findings of lissencephaly in a mixed breed dog. Journal of Veterinary Medical Science. v.73, n.10, p.1385-1388, 2011. Available from: $<$ https://www.jstage.jst. go.jp/article/jvms/73/10/73_11-0117/_article $>$. Accessed: Sept. 10, 2015. doi: 10.1292/jvms.11-0117.

MACKILLOP, E. Magnetic resonance imaging of intracranial malformations in dogs and cats. Veterinary Radiology \& Ultrasound, v.52, n.1, Supp.1, p.S42-S51, 2011. Available from: <http:// onlinelibrary.wiley.com/doi/10.1111/j.1740-8261.2010.01784.X/abs tract;jsessionid=22E415476FD93E6B174E1C74BFE86D8E.f02t02 ?userIsAuthenticated $=$ false $\&$ deniedAccessCustomisedMessage $=>$. Accessed: Feb. 10, 2015. doi: 10.1111/j.1740-8261.2010.01784.

OBERST, R.D. Viruses as teratogens. Veterinary Clinics of North America: Food Animal practice, v.9, n.1, p.23-31, 1993. Available from: $<$ http://www.ncbi.nlm.nih.gov/pubmed/8384522>. Accessed: Jan. 20, 2016. 
PÉREZ,V.et al. Hereditary lissencephaly and cerebellar hypoplasia in Churra lambs. BioMed Central Veterinary Research, v.9, n.156, p.1-11, 2013. Available from: <http://www.biomedcentral.com/17466148/9/156/> . Accessed: Jan 17, 2015.doi: 10.1186/1746-6148-9-156.

PILZ, D. et al. Neuronal migration, cerebral cortical development, and cerebral cortical anomalies. Journal of Neuropathology and Experimental Neurology, v.61, n.1, p.1-11, 2002. Available from: <http://journals.lww.com/jneuropath/Abstract/2002/01000/ Neuronal_Migration,_Cerebral_Cortical_Development,.1.aspx $>$. Accessed: Mar. 07, 2015.

SANTOS, A.S. et al. Clinical, pathological, immunohistochemical and viral aspects of five calves persistently infected with bovine viral diarrhea virus in a farm of Rio Grande do Sul, Brazil. Pesquisa Veterinária Brasileira, v.31, n.10, p.885-892,2011. Available from: $<$ http://www.scielo.br/scielo.php?script=sci serial\&pid=0100-736X\&lng $=$ en\&nrm $=$ iso $>$. Accessed: Jan. 13, 2016. doi: 10.1590/S0100-736X2011001000009.

SANTOS, J. R. S. et al. Lissencephaly and cerebellar hypoplasia in a goat. Ciência Rural. v.43, n.10, p.1858-1861, 2013.
Available from: <http://www.scielo.br/scielo.php?pid=S0103$84782013001000020 \&$ script $=$ sci_arttext $>$. Accessed: Mar. 07, 2015. doi: 10.1590/S0103-84782013001000020.

SUÁREZ-VEGA, A. et al. Identification of a 31-bp Deletion in the RELN Gene Causing Lissencephaly with Cerebellar Hypoplasia in Sheep. PLOS ONE, v.8, n.11, p.e81072. Available from: $<$ http://journals.plos.org/plosone/article?id=10.1371/journal. pone.0081072>. Accessed: Jan. 13, 2016.

TIAN, G.et al. A pachygyria-causing $\alpha$-tubulin mutation results in inefficient cycling with CCT and a deficient interaction with TBCB. Molecular Biology of the Cell, v.19, p.152-1161, 2008. Available from: <http://europepmc.org/abstract/med/18199681>. Accessed: Mar. 08, 2015.doi: 10.1091/mbc.E07-09-0861.

WYNSHAW- BORIS, A. et al. Lissencephaly: mechanistic insights from animal modeland potential therapeutic strategies. Seminars in Cell \& Developmental Biology, v.21, p.823-830, 2010. Available from: <http://www.sciencedirect.com/science/ article/pii/S1084952110001242>. Accessed:Mar. 03, 2015. doi: 10.1016/j.semcdb.2010.07.008. 